\title{
EFFECT OF SOCIAL MEDIA USAGE AND ENTREPRENEURIAL MARKETING ON THE SUCCESS OF ORGANIC PROCESSED FOOD MSMES
}

\author{
Nanda Nur Rafiana*1, Ma'mun Sarma*), Mukhamad Najib*) \\ ${ }^{*}$ Department of Management, Faculty of Economics and Management, IPB University \\ Jl. Kamper, IPB Dramaga Campus, Bogor 16680, Indonesia
}

\begin{abstract}
Social media usage has been adopted by entrepreneurs to achieve business goal. The rise of health and sustainability awareness has opened an opportunity for entrepreneurs to start organic processed food business despite the marketing obstacle about organic food informations. Entrepreneurial marketing is considered as a more appropriate marketing approach for limitation in MSMEs which is able to indicate the perception of entrepreneurs who use the social media for overcoming technology and information resource obstacle. This study was aimed to analyze effect of social media usage and entrepreneurial marketing on the success of organic processed food MSMEs based on the analysis of Structural Equation Modelling (SEM) with Partial Least Squares (PLS). The study was conducted on Komunitas Organik Indonesia in Greater Jakarta (Jabodetabek) with a total population of 400 MSMEs from December 2020 to March 2021. The data source used was primary data that was collected from 63 respondents which use social media on business need. Based on result of SEM analysis, the use of social media for marketing, customer relation and service, and accessibility of information have a significant and positive effect on entrepreneurial marketing. Moreover, social media usage for marketing and information accessibility was found to have direct effect which could increase business success even though social media usage for customer relation and service did not affect business success. On the other hand, entrepreneurial marketing also directly influenced business success. The use of social media together with application of entrepreneurial marketing will have effect on business success.
\end{abstract}

Keywords: social media usage, entrepreneurial marketing, business success, MSMEs of organic processed food, SEM-PLS

\begin{abstract}
Abstrak: Penggunaan media sosial telah diadopsi oleh pelaku usaha untuk mencapai tujuan usaha. Terbentuknya kesadaran akan kesehatan dan keberlanjutan membuka peluang bagi pelaku usaha untuk merintis usaha makanan olahan organik meskipun terdapat kendala pemasaran tentang informasi makanan organik. Entrepreneurial marketing dianggap sebagai pendekatan pemasaran yang lebih tepat untuk keterbatasan di UMKM mengindikasikan persepsi pelaku usaha dalam menggunakan sosial media untuk mengatasi keterbatasan sumber daya teknologi dan informasi. Penelitian ini bertujuan untuk menganalisis pengaruh penggunaan sosial media dan entrepreneurial marketing terhadap keberhasilan UMKM makanan olahan organik berdasarkan analisis Structural Equation Modeling (SEM) dengan Partial Least Squares (PLS). Penelitian dilakukan pada Komunitas Organik Indonesia Jabodetabek dengan total populasi 400 UMKM pada Desember 2020 hingga Maret 2021. Sumber data yang digunakan adalah data primer yang dikumpulkan dari 63 responden yang menggunakan sosial media untuk keperluan usaha. Berdasarkan hasil analisis SEM, penggunaan sosial media untuk pemasaran, hubungan dan layanan pelanggan, dan aksesibilitas informasi berpengaruh signifikan dan positif terhadap entrepreneurial marketing. Selain itu, penggunaan sosial media untuk pemasaran dan aksesibilitas informasi memiliki pengaruh langsung yang dapat meningkatkan keberhasilan usaha meskipun penggunaan sosial media untuk hubungan dan layanan pelanggan tidak mempengaruhi keberhasilan usaha. Di sisi lain, entrepreneurial marketing juga secara langsung mempengaruhi keberhasilan usaha. Penggunaan sosial media bersama dengan penerapan entrepreneurial marketing akan berpengaruh pada keberhasilan usaha.
\end{abstract}

Kata kunci: penggunaan sosial media, entrepreneurial marketing, keberhasilan usaha, UMKM makanan olahan organik, SEM-PLS

\footnotetext{
${ }^{1}$ Corresponding author:

Email: nanda.rafiana@gmail.com
} 


\section{INTRODUCTION}

The growth of MSMEs necessarily contributes to the economy of Indonesia. This sector plays quite an important role concerning its contribution to Gross Domestic Product (GDP) of Indonesia. MSMEs are also considered as the backbone of economic growth in many countries. They contribute in providing job opportunities and act as supplier of goods and services to large organization (Singh et al. 2008). Increase in the contribution of MSMEs sector to the GDP is in line with the increasing number of MSMEs. According to the Indonesia Ministry of Cooperatives and MSMEs (2018), MSMEs sector contributed to 60\% GDP in 2017 which increased to $61.4 \%$ in 2018 along with the increasing number of MSMEs from 62.92 million business unit in 2017 to 64.19 million business unit in 2018.

In order to optimize the potential of MSMEs which provides support for economic growth in this digital era, it is important for MSMEs to apply information technology for marketing activity. According to the surveyconducted by the IndonesiaAssociation ofInternet Service Provider (2018), penetration of internet user in Indonesia has increased from 142.26 million people in 2017 to 171.17 million people in 2018. Based on the result of survey conducted by Indonesian Association of Internet Service Provider (2018), accessing social media ranked first (19.10\%) as the reason people mostly used the internet. The benefit of social media is not only to expand social circle within personal life, but also provide an advantage to the practice of small business. The owners of small business cannot always rely on the traditional communication channel to obtain, maintain, and increase the number of customer, yet they have to use the emerging communication and network platform as well as other social media tools to help achieving business goal (Jones 2010).

Social media as a technology and information facilitates two-way communication between customers and organizations that distinguishes it from other ICT applications. Parveen et al. (2016) explained terms like social media, social networks, blogs and online communities are all ideas incorporated within the philosophy known as Web 2.0. The subject using the technology is the organization, the technology is the social media, and the task is the social media usage for various purposes like advertising, branding, building relations, etc. In order to investigate the usage of social media in organizations, the informed effective use of social media was considered, as this was an important indication of technology success, which in turn has an impact on organizations (DeLone and McLean, 2003). Parveen et al. (2016); Dodokh and Al-Maaitah (2019) categorize the use of social media into three sub-constructs adapted from previous research, such as Papastathopoulou and Avlonitis (2009); Elliot and Boshoff (2005); Moen et al. (2008); Teo and Choo (2001). The three sub-constructs consists of the use of social media for marketing, social media for customer relation and service, social media for information accessibility. It analyze the effect of these three subconstructs directly and partially on organizational performance.

Marketing is an important activity for entrepreneurs because every business is expected to survive and thrive. According to Kraus et al. (2010), the concept of marketing (traditional marketing) was originally developed for large firm, the basic concept of marketing mix in traditional marketing requires high cost, particularly in promotion activity and sales advertising, thus cannot be directly transferred to small business without adaptation.

In its development, MSMEs face many obstacles related to competitiveness and MSMEs performance, such as the limited access to capital, limited access to market, and limited access to information about resources and technology (Hubeis et al. 2016). In terms of the limited resources and problems found in MSMEs, entrepreneurial marketing is considered a more appropriate contingency approach. The concept of entrepreneurial marketing is the reflection of proactive attitude of entrepreneurs to identify and exploit various opportunities to obtain and maintain customers through many innovative approaches, risk management, resource optimization, creation of value added, and also maintaining relationship with stakeholders through various entrepreneurial characteristics as the basic concept (Sarma, 2013). Moreover, Jones and Rowley (2011) suggested further development of entrepreneurial marketing concept towards entrepreneurial marketing orientation. This concept shows that marketing in SMEs is related to other activity and behavior in small business. Based on literature analysis of entrepreneurial marketing, Jones and Rowley (2011) considered that entrepreneurial 
marketing should include innovation and customer relation involvement. Paradigm of entrepreneurial marketing should be necessarily improved to include, not only knowledge-based marketing approach, but also innovation, entrepreneurship, involvement, and customer relation. This philosophical point of view is operationalized through focus on orientation.

The use of technology and information nowadays has changed the way to run business, particularly in solving the problem of limited MSMEs resources. Through the development of technology, information about this opportunity is also caught by several entrepreneurs to identify and exploit new market compared rather than serving the existed market. The rise of consumer awareness about health and safety food that is healthy and chemical free has opened an opportunity for entrepreneurs to start organic processed food business. Muzayanah et al. (2015) mentioned that the obstacle in organic marketing is information about organic product. Therefore, integrated promotion is required to raise public awareness besides expanding market for organic.

The current social media mostly used by many people is hoped to be able to deal with information obstacle about the presence of organic processed food product and achieve business success. Business performance of firm is of the goals to be achieved by each entrepreneurs. Business performance of small industry is defined as success rate in achieving the expected goals (Purnama and Suyanto, 2010). According to Purnama and Suyanto (2010), the performance of small industries can be defined as the level of success in achieving the purpose or the expected goals. It can be seen from various aspects, such as finansial performance, corporate image, production efficiency, expanding production, profitability and public confidence. However, based on the research of Ministry of Cooperatives and MSMEs (2018), there was only 13\% go-digital SMEs of total 64 million SMEs in Indonesia. Based upon the survey of Katadata Insight Center (2020), the highest percentage of 24\% MSMEs entrepreneurs in the Greater Jakarta (Jabodetabek) experienced digital marketing problem due to lack of knowledge in running online business. Hence, it is necessary to conduct research about the effect of social media use was categorized into three subconstructs namely social media for marketing, social media for customer relation and service, and social media for information accessibility on the entrepreneurial marketing and the success of organic processed food MSMEs. Moreover, this study also investigate effect of entrepreneurial marketing on the success of organic processed food MSMEs.

\section{METHODS}

The survey was conducted on Komunitas Organik Indonesia (the Indonesian Organic Community) from December 2020 to March 2021. The data source used were primary data obtained from online distribution of questionnaire via whatsapp with the Google form application to MSMEs entrepreneurs involved in Komunitas Organik Indonesia in Greater Jakarta (Jabodetabek). Furthermore, secondary data were collected from various sources of literature related to the study, such as journal, previous study, and internet. In terms of questionnaire, likert scale based on level of respondent agreement was used as measurement scale for each indicator with score range from 1 (strongly disagree) to 5 (strongly agree).

A total of 400 MSMEs involved in Komunitas Organik Indonesia in the Greater Jakarta (Jabodetabek) were determined as population in this study. Number of respondents selected as research sample amounted to 63 MSMEs, based on the respondents' respond to the online questionnaire. Number of respondents was done following the recommendation of Ghozali (2008) according to the analysis tool applied, namely Structural Equation Model Partial Least Square (SEMPLS) with recommended minimum sample size of 30100 samples. Sample collection was done through the technique of purposive sampling. The criteria applied for sample determination are: (1) organic processed food SMEs; (2) entrepreneurs used social media for business purpose; (3) those domiciled in Greater Jakarta (Jabodetabek).

Data analysis used in this study included descriptive analysis and Strucural Equation Modeling-Partial Least Squares (SEM-PLS). Descriptive analysis was applied to explain the characteristics of entrepreneurs, characteristics of business, and implementation of social media use. Analysis of SEM PLS was used to analyze the effect of social media use and entrepreneurial marketing on business success. Partial Least Squares (PLS) is a powerful method of analysis and is often referred to as soft modeling because it 
negates OLS (Ordinary Least Square) assumptions such as regression. SEM-PLS usually consists of two sub-models, namely, the measurement model or outer model and the structural model or inner model (Ghozali, 2008). There are five variables in the model, five variables such as social media usage that consists of three variables, namely social media for marketing (X1), social media for customer relation and service (X2), social media for information accessibility (X3), entrepreneurial marketing (Y1) and business performance (Y2). Businees performance variable is used because one of the factors of business success is if the performance of its business gives a positive inluence on a business (Afifah et al. 2018). Table 1 illustrates research hypothesis that variables of social media usage for marketing (X1), customer relation and service (X2) and information accessibility (X3) were used to analyze their positive effect on entrepreneurial marketing (Y1) and business performance (Y2) directly and partially. It indicates that good optimization in social media usage for marketing, customer relation and service, and information accessibility, would increase entrepreneurial marketing capabilities and business performance. This study also analyze positive effect of entrepreneurial marketing (Y1) on business performance (Y2) that showed in Table 1. Moreover, it indicates an increase in entrepreneurial marketing ability, would increase business performance. Construct of path diagram explains relationship pattern between latent variables and indicator. Moreover, path diagram also shows the relationship between the causal flow and endogenous and exogenous latent variables (Ghozali and Latan, 2015) as illustrated by research conceptual framework in Figure 1. The hypotheses in Table 1 are formulated in Figure 1 that shows the conceptual research framework.

Table 1. Research hypothesis

\begin{tabular}{cll}
\hline Hypothesis & Description & Path \\
\hline H1a & Social media for marketing (X1) positively affects entrepreneurial marketing (Y1) & $\mathrm{X} 1 \rightarrow \mathrm{Y} 1$ \\
H1b & Social media for marketing (X1) positively affects business performance (Y2) & $\mathrm{X} 1 \rightarrow \mathrm{Y} 2$ \\
$\mathrm{H} 2 \mathrm{a}$ & Social media for customer relation and service (X2) positively affects entrepreneurial marketing & $\mathrm{X} 2 \rightarrow \mathrm{Y} 1$ \\
& & \\
& & \\
H2b & Social media for customer relation and service (X2) positively affects business performance (Y2) & $\mathrm{X} 2 \rightarrow \mathrm{Y} 2$ \\
H3a & Social media for information accessibility (X3) positively affects entrepreneurial marketing (Y1) & $\mathrm{X} 3 \rightarrow \mathrm{Y} 1$ \\
H3b & Social media for information accessibility (X3) positively affects business performance (Y2) & $\mathrm{X} 3 \rightarrow \mathrm{Y} 2$ \\
H4 & Entrepreneurial marketing (Y1) postively affects business performance (Y2) & $\mathrm{Y} 1 \rightarrow \mathrm{Y} 2$ \\
\hline
\end{tabular}

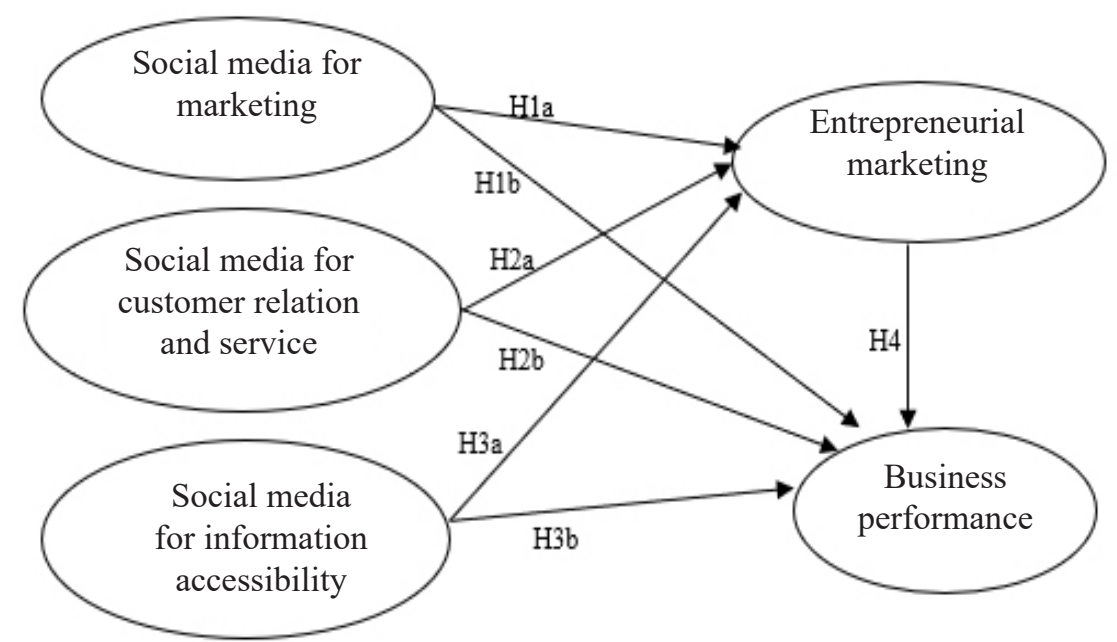

Figure 1. Research framework 


\section{RESULT}

\section{Characteristics of Entrepreneurs and Business}

Result of the study is concluded based on the majority answer in questionnaire given by respondents. Most entrepreneurs $(46.0 \%)$ were domiciled in Jakarta, dominated by female (69.8\%) in age range of 30-40 years old (44.4\%) and about $90.5 \%$ have attended formal education up to higher education level. Before starting business, entrepreneurs were majorly worked as private sector employees $(69.8 \%)$ and the reason of $57.1 \%$ people to start business was due to the hope for profitable opportunity. Hence, $42 \%$ of entrepreneurs said they would never leave their business. In majority, $92.1 \%$ of respondents had not participated in family business and $44.4 \%$ mentioned they had never leave their region while running their business.

Entrepreneurs were considered beginner and had recently started their business. Entrepreneurs majorly had business experience for 1-3 years (63.5\%) and mostly had 1-4 employers (82.5\%) with majority average monthly revenue of 2 - 9 million (52.4\%). Entrepreneurs confirmed that they still worked (46\%) while doing business, thus their business was not the main source of family income (49.2\%) and they were able to fulfil $0-25 \%$ of family need $(61.9 \%)$.

\section{Implementation of Social Media Use}

Social media mostly used was Instagram (53.0\%), and some of them also use other social media tools such as Facebook (31.6\%), WhatsApp (6.0\%), Google+ (3.4\%), Pinterest $(1.7 \%)$, Tik Tok $(1.7 \%)$, Twitter $(0.9 \%)$, LinkedIn $(0.9 \%)$ and You Tube $(0.9 \%)$. Most entrepreneurs had already used social media for marketing their product for about $1-2$ years $(33.3 \%)$, followed by $27.0 \%$ of the entrepreneurs have been using it for more than 2 years. Moreover, about $22.2 \%$ of the entrepreneurs have been using it for 6 months to 1 year and only about $17.5 \%$ of them have been using it less than 6 months. Entrepreneurs also had a high online frequency in using social media (49.2\%) as they averagely need 1 hour to respond to their customer, and about $38.1 \%$ of th entrepreneurs replied that they respond within a day.

\section{Analysis of Structural Equation Modelling-Partial Least Square}

Analysis of Structural Equation Modelling through the approach of Partial Least Square(SEMPLS) was applied to examine the relationship between latent variables and also the relationship between latent variable and its construct indicator. In SEM PLS analysis, two analysis of model evaluation, namely outer model evaluation or usually called measurement model evaluation and inner model evaluation or often called structural model evaluation.

\section{Evaluation of Measurement Model (Outer Model)}

Prior to evaluation of measurement model(outer model), evaluation of convergent validity was performed which included measurement of loading factor and the value of Average Variance Extracted (AVE). Ghozali and Latan (2015) mentioned that construct would have an ideal validity value if loading factor value $>0.7$ and AVE value $>0.5$. Based on the result of outer model evaluation, eleven indicators were found to have loading factor value $<0.7$ (Figure 2), thus they were removed from the model. Moreover, in order to obtain the best model, the process was repeated without including those indicators. Through a number of iterations, the final measurement model was obtained, showing that all indicators had loading factor value $>0.7$ as presented in Figure 3. Furthermore, each latent variable resulted in AVE value $>0.5$ as seen in Table 2 .

The next measurement was model testing for reliability to examine accuracy, consistency, and precision of instrument in measuring variable. Tabel 2 shows that all latent variables were reliable, accurate, and consistent with composite reliability value $>0.7$ for each latent variable. Discriminant validity test produced greater root of AVE value of each variable compared to the value of correlation between latent variables. It informed that latent variable had a high discriminant validity.

\section{Evaluation of Structural Model (Inner Model)}

Evaluation of inner model is aimed to depict and predict causal relationship between latent variables. Parameter used for inner model evaluation included coefficient of determination (R-square), hypotheses testing, and path coefficient estimates. Based on the result of data analysis, endogenous latent variable of entrepreneurial marketing produced R-Square of 0.581 , 
indicating that $58.1 \%$ of variance of entrepreneurial marketing is explained by the model, while the rest $41.9 \%$ is explained by other factors outside the model. Moreover, variable of business performance generated R-Square of 0.583 . It means that $58.3 \%$ of variance of business performance is explained by model, while the rest $41.7 \%$ is explained by other factors outside the model.
Hypotheses testing and path coefficient estimates were performed to investigate the value of t-statistics as the basis for assessing significant effect of a construct. Hypotheses testing of a variable is considered affecting other variable if the value of t-statistics is greater than the value of t-table 1.96 at alpha $5 \%$, as showing by the result of bootstraping in Table 3.

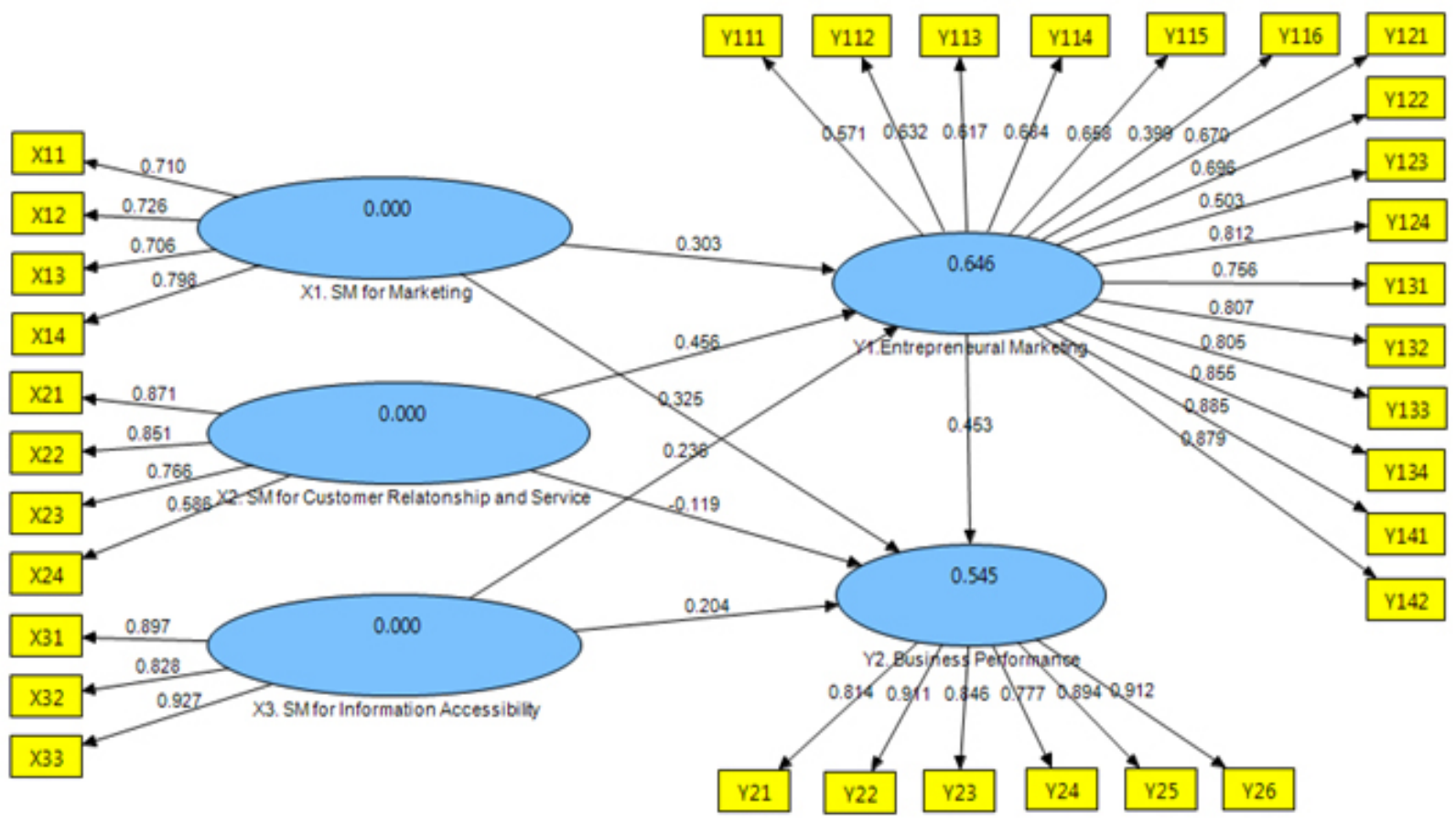

Figure 2. Loading factor on Initial Measurement Model

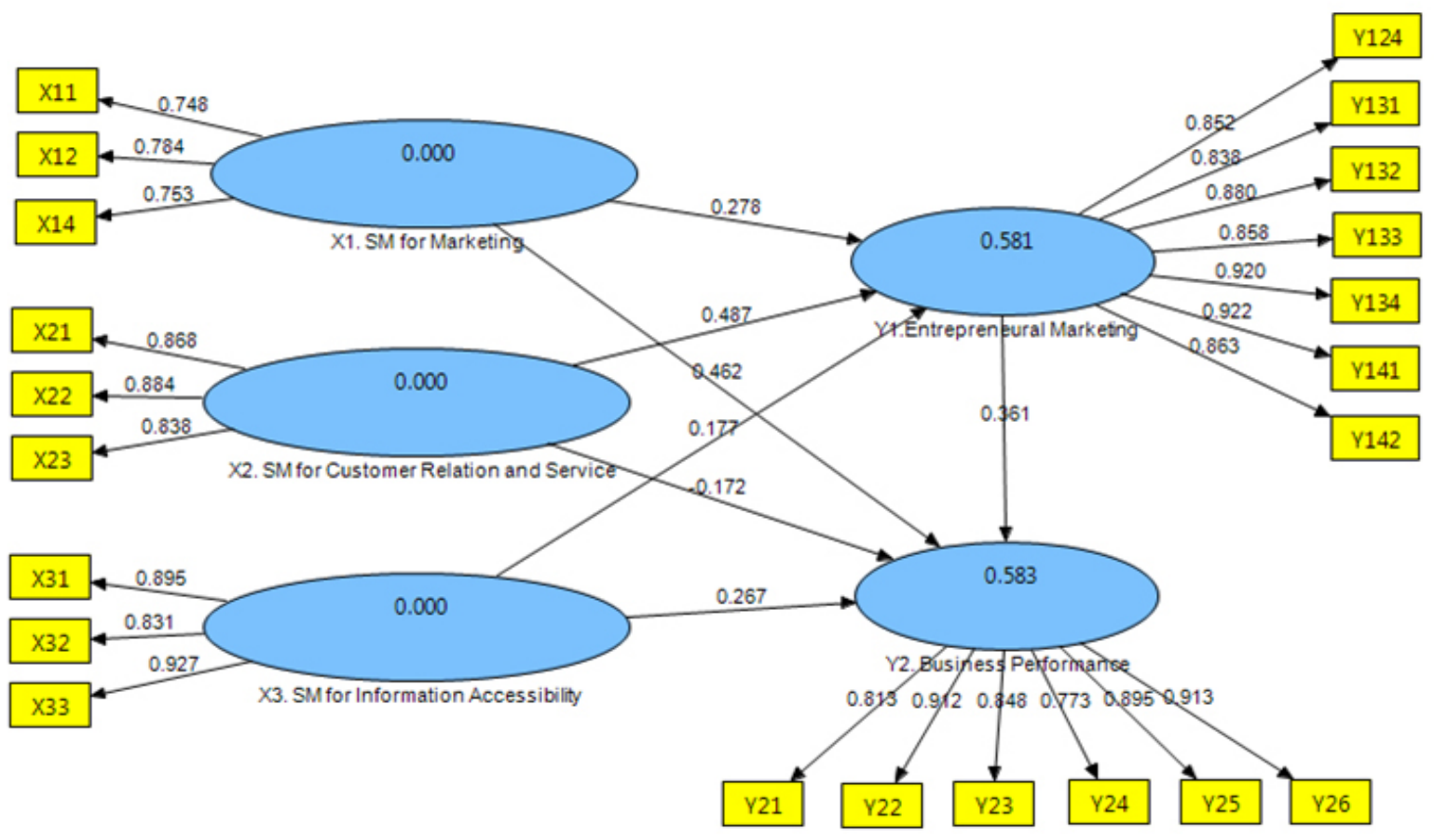

Figure 3. Loading factor on Final Measurement Model 
Table 2. Construct reliability and convergent validity

\begin{tabular}{lcc}
\hline Variabel & AVE & Composite Reliability \\
\hline Social Media for Marketing & 0.580 & 0.806 \\
Social Media for Customer Relationship and Service & 0.746 & 0.898 \\
Social Media for Information Accessibility & 0.784 & 0.916 \\
Entrepreneurial Marketing & 0.769 & 0.959 \\
Business Performance & 0.741 & 0.945 \\
\hline
\end{tabular}

Table 3. Path coefficients and hypotheses testing

\begin{tabular}{lccc}
\hline Hypothesis & Coefficient & t-Value & Result \\
\hline SM for marketing $\rightarrow$ entrepreneurial marketing & 0.278 & 2.701 & Supported \\
SM for customer relation and service $\rightarrow$ entrepreneurial marketing & 0.487 & 3.951 & Supported \\
SM for information accessibility $\rightarrow$ entrepreneurial marketing & 0.177 & 2.042 & Supported \\
SM for marketing $\rightarrow$ business performance & 0.462 & 4.534 & Supported \\
SM for customer relation and service $\rightarrow$ business performance & -0.172 & 1.734 & Not Supported \\
SM for information accessibility $->$ business performance & 0.267 & 2.282 & Supported \\
Entrepreneurial marketing $->$ business performance & 0.361 & 2.508 & Supported \\
\hline
\end{tabular}

\section{Hypotheses Test}

Based on the result of bootstraping, out of the total of 7 hypotheses, there are 6 hypotheses accepted and resulted in significant effect, namely $\mathrm{H} 1 \mathrm{a}, \mathrm{H} 1 \mathrm{~b}, \mathrm{H} 2 \mathrm{a}$, $\mathrm{H} 3 \mathrm{a}, \mathrm{H} 3 \mathrm{~b}$ and H4. Whereas, one hypothesis which provided insignificant effect is $\mathrm{H} 2 \mathrm{~b}$ with value of t-statistics $<$ t-table 1.96 at alpha $5 \%$.

\section{Effect of Social Media for Marketing on Entrepreneurial Marketing}

According to the value of path coefficient, variable of social media for marketing significantly affected entrepreneurial marketing with path coefficient of 0.278 and t-statistic of 2.701. The goal of social media for marketing is to produce content to be further shared by the user with their social network to help firm increasing brand exposure and expand customer reach (Iblasi et al. 2016). According to Hadiyati (2009), the concept of entrepreneurial marketing includes the exploration of values, skill, and behavior of an entrepreneur when dealing with problem and identifying business opportunities. Social media has a great potential for entrepreneurs to develop effective marketing strategy (Azhar and Akhtar, 2020). The benefit possibly obtained by entrepreneurs from social media is including the opportunity to increase exposure, boost social media traffic, develop effective marketing strategy, increase the number of loyal customer, also reduce marketing cost (Azhar and Akhtar, 2020). A business could easily build its own brand to increase business activity through social media (Walsh and Lipinski, 2009).

This finding was in line with Saavedra et al. (2012) as business actively participated in online social networking and deceloped strategy or invested in social media marketing, or community manager, and digital marketing agent, entrepreneurs could gain profit from online social networking potential as marketing tool. It was consistent with the study conducted by Araujo et al. (2015), when business posted useful material on social media, customers were likely to share or reply their friends' comment. Ojeleye et al. (2018) found that social media, in this case: Facebook, WhatsApp, and Instagram, significantly contributed to business development while ensuring entrepreneurs also develop themselves in entrepreneurial creativity. In fact, social network activity was found to be able to increase the co-creation activity of MSMEs (Shiau et al. 2017; Yoon and Cho, 2016).

In this study, entrepreneurs were observed to be skillful in posting contents in different types, such as infographic, video, flyer, advertisement, and photograph, also various attractive, informative, and educative articles. Besides product promotion, the content also contained educative information about the benefit, advantage, and importance of consuming organic processed foods for the personal and family health, and environment. 


\section{Effect of Social Media for Customer Relation and Service on Entrepreneurial Marketing}

Social media for customer relation and service had significant effect on entrepreneurial marketing with path coefficient of 0.487 and t-statistic of 3.951. This result was in line with the study of Wibowo et al. (2020) that social media could be used by firm to establish direct communication and good relationship with customers. Interactive nature of social media facilitated relationship improvement (Parveen et al.2016). Marketing aspect, such as relation and communication, is important since SMEs are normally close to their customers besides its function as a compatible marketing activity aspect concerning resource constraints experienced by micro, small, and medium enterprises (Carson and Gilmore, 2000). The social media platform has become an instrument which eases the creation of online communication between consumers and firm, or between consumers around the world, particularly for SMEs, by reason of their limited resources, both in term of finance, technical knowledge, and any other obstacles (Harris et al. 2008; Rana et al. 2019). Social media has the ability to reach more customers while fulfilling specific needs of their customers in a better way. This indicates that social media could help business to run effectively and efficiently along with its ability to create such innovative strategy which will speed up business (Singh and Sinha, 2017).

The study result was also in accordance with previous study, showing that social media use was able to increase value to a business since it allowed business to directly connect to customers, particularly those in different geographical zone (Kimani, 2015). Social media use could also help micro, small, and medium enterprises (MSMEs) to reach global market with minimal effort and cost (Cappuccio et al. 2012). Social media is indeed a media with ability to develop entrepreneurial intention. Tool and technique of social media could expand the bigger scope of market access and closer relationship with customers (Jagongo and Kinyua, 2013). The use of social media (Facebook, Instagram, Twitter, etc.) is proven to assist and contribute to content creation, increase interaction with customers, and improve effective communication among stakeholders (Berthon et al. 2012; Koç \& Dündar, 2018; Sunar and Syari, 2017; Wu and Pei, 2018; Okoroma, 2018; Samat et al. 2018).
The feature of chat box or comment box and direct message on social media provided such way for entrepreneurs to interact, communicate, and serve customers. Social media helped entrepreneurs to reply comment and message, respond to compliment and suggestion, answer question, and serve product ordering from customers without geographical and time limit. Interactive nature of social media has created a twoway communication between organization and public, resulting in a better relationship (Parveen et al. 2016). Based on the information obtained, entrepreneurs are able to approach customers through social media. Most customers are already aware of healthy lifestyle, hence social media is considered a better way to reach a broader scope of customers. Social media is believed to be a more effective platform for its wider application user base and its advantage in facilitating interaction with customers. Business organization will be surely motivated to actively respond to the needs and even complaints of customers. Business organization will be surely motivated to actively respond to the needs and even complaints of customers. Social media will also create various innovations in business organization since it is supported by good communication with customers, input from customers, and feedback (Richard et al. 2009).

\section{Effect of Social Media for Information Accessibility on Entrepreneurial Marketing}

Social media for information accessibility also significantly influenced entrepreneurial marketing with path coefficient of 0.177 and t-statistic of 2.042. This finding confirmed the study performed by McKelvie and Wiklund (2004) that determination of market value according to change in new technology positively affected the identification of business opportunity. Other finding by Park et al. (2017) mentioned that entrepreneurs with higher sense of vigilance tended to assess market change to identify potential entrepreneurial opportunity using social media. Opportunity is created by accessing new information and re-combining innovative entrepreneurial resource by use of social media in scanning, searching, and connecting information in market (Park et al. 2017).

Social media provided easy access to information from many sources in external environment of a firm. Social media provides more information about business competitors, action, strategy, and public perspective which will help business to improve business product 
and services (Stone et al. 2007). Market intelligence of entrepreneurs will necessarily monitor the market, particularly their competitors (Stokes 2000). Information obtained from social media will provide knowledge for entrepreneurs about customers, competitors, market, and trend of change in consumers which basically helped entrepreneurs to improve and develop strategy concerning new products or services, hence allowing entrepreneurs to customize goods and services according to customer needs. The data obtained from social media help firm in providing product and services needed by consumers (Dwivedi et al. 2021).

Social media could facilitate intelligence collection from customers and uses it to produce innovative products, such as new package, product delivery, and payment method (Jagongo and Kinyua, 2013). This includes the technique to run business or offer product and innovative service which could also be communicated with customers through social media. Based on the information obtained in this study, entrepreneurs confirmed that they were able to obtain information about market target and segmen market from social media. Moreover, social media places first as platform used by consumers to search for information about healthy lifestyle products. Based on the information obtained in this study, entrepreneurs were able to find information about popular trend through social media. During Covid 19 pandemic today, consumers were observed to share lot of information to entrepreneurs to create idea and innovate, thus business is more targeted in following the flow of consumer change through social media. Entrepreneurs have noticed that social media use are currently more aware about health aspect including organic food product during the Covid 19 pandemic. Evans and McKee (2010) observed that the use of social media technology has provided knowledge and idea about innovative ways to serve customers.

\section{Effect of Social Media for Marketing on Business Performance}

Social media for marketing had significant effect on business performance with path coefficient of 0.462 and t-statistic of 4.534. This result was consistent with study carried out by Sufian et al. (2020) who found linkage between customers and sales performance, where involvement through electronic word of mouth will strengthen product quality, attract more customer, and boost sales. Ismail (2017) also found that responding to customers' comment and post will intrigue customers while getting feedback which effectively increase the loyalty of small business customer and increase revenue. Social media marketing could increase business profit by increasing visibility. This has been the main reason of social media use by entrepreneurs as it is able to attract new customers and boost sales (Olanrewaju et al. 2018). The use of social media in a business could reduce marketing cost, hence improving business performance by increasing income (Amalia and Mahendrawati, 2019). According to Bocconcelli et al. (2017) social media is considered as a valuable resource of SMEs in sales besides as a more planned and proactive sales approach.

Various posts of content provided different way to display product in online store such as social media, compared to that in offline store. In this study, the content of product promotion was also presented on the business account page of entrepreneurs. Product promotion was done by doing price promotion, sharing customer testimony in interactive content, and doing product giveaway through electronic word of mouth. Feedback given by customers for sharing experience regarding certain brand, product, or service will increase preference of other customers for the product, resulting in decision to purchase which will further increase sales. Feedback from consumers, such as electronic word of mouth will increase online presence, interaction, and sales (Grossberg, 2016).

\section{Effect of Social Media for Customer Relation and Service on Business Performance}

Social media for customer relation and service was found to have no significant effect on variable of business performance. It is shown by the value of t-statistic that is less than t-table $(1.734<1.96)$. This insignificant result between social media for customer relation and service and business performance was in line with the study performed by Arfanly et al. (2016) which showed that the situation was due to low capability of entrepreneurs to establish relationship with consumers. This was also considered in line with the result of study performed by Buss and Begorgis (2015) which showed that positive impact on performance of customer relation was not achieved through social media use. Social media is not the most effective tool for customer relation management, however, weak relationship was found, thus social media was used in addition to the activity of consumer relation management of established firm (Buss and Begorgis, 2015). Other finding of Guha et al. (2017) indicated that SMEs tended to not use social 
media to make important and strategic decision or to measure the indicator of customer relationship management.

In this study, most businesses were at micro scale and recently started. Social media was only used to interact, communicate, and serve customers at real time without any geographical and time limit. Hence, they only used social media to reply comment and message, respond to compliment and suggestion, answer question, and serve product ordering from customers. It is expected that they did not yet understand that customer relationship management should be the focus of strategy to improve service and personally and sustainably establish good relationship with old and new customers as it is the strategy to create customer loyalty and satisfaction in the long term. Even though SMEs have been aware of the opportunity offered by social media, some only use it particularly as marketing tool (Srinivasan and Moorman, 2005), normally in the absence of social media customer-centric strategy which is formally defined (Giannakouris and Smihily, 2013). This often leads to low intensity of social media use to manage customer relationship besides opportunity lost (Marolt et al. 2020).

\section{Effect of Social Media for Information Accessibility on Business Performance}

Social media for information accessibility was also observed to have significant effect on business performance with path coefficient of 0.267 and t-statistic of 2.282. Result of this hypothesis testing was confirmed by research conducted by Scheiner (2014) that social media has created new external information source which increasingly expand the search field of business environment. Information technology in the form of social media is the key factor for achieving competitive advantages and ensuring profitability for business survival. The finding of Ndiege (2018) indicated that social media successfully increased accessibility of information between customers and MSMEs, thus contributing to symmetrical information in market. Social media is used to provide rich information along with better customer support which is able to quickly increase annual sales and financial profit (Coen, 2016). The use of social media to search for information could predict or create latest trend in the community, that mastering market knowledge will increase the effectiveness of business organization (Amalia and Mahendrawathi 2019). By using social media, firm will be able to investigate valuable information about competitor. This will help firm to understand the habit and strategy of competitor which will further lead to competitive advantage and help strategic planning (Dey et al. 2011; Eid et al. 2019; Teo and Choo, 2001).

Social media can be used to acquire consumer and market knowledge (Kazienko et al. 2013). Change in consumer behavior during Covid-19 pandemic provided information for organic processed food entrepreneurs through social media to be more competent in dealing with this situation. Other change that appeared was that consumers were currently more aware of issues concerning health, nutrition, healthy lifestyle, and immunity. Consumers were found to be more selective about processed foods, particularly healthy food also clean and healthy food intake for daily consumption. Information obtained from several social media platforms can be used for different marketing purposes, such as understanding consumers' needs and preference, marketing potential of new product or service, and current market trend (Agnihotri et al. 2016; Constantinides et al. 2008). Social media is also considered as tool that is able to help entrepreneurs to integrate business practice and sustainability (Sivarajah et al. 2019).

Change in consumer behavior during Covid-19 pandemic provided information for organic processed food entrepreneurs through social media to be more competent in dealing with this situation. The ability to interprete consumers' needs and wants from the data obtained on social media is an essential business skill to master (Amalia and Mahendrawathi, 2019). Online sales system with minimum physical interaction has greatly help business to maintain the sales rate of product amidst the limited activity to do during pandemic and consumer awareness to maintain immunity.

\section{Effect of Entrepreneurial Marketing on Business Performance}

Entrepreneurial marketing significantly influenced business performance with path coefficient of 0.361 and t-statistic of 2.508. This finding confirmed the study done by Becherer et al. (2012), Reijonen et al. (2012), Arfanly et al. (2016), Rusminah et al. (2019) which concluded that the strategy of entrepreneurial marketing had positive effect on the increasing business performance since one of the factors of business success is when its business performance has a positive effect on business. 
Current Covid 19 pandemic has caused entrepreneurs, with their knowledge structure, to always learn to adapt and be responsive to changes in customer behavior who mostly perform online activity. Open-mindedness and knowledge have caused organic processed food entrepreneurs to adapt to consumer needs today. Entrepreneurs should look for knowledge about current market situation, market demand, and other things that become the trend flow (Afifah et al. 2018). In this study, entrepreneurs paid special attention to the trend and further quickly and properly applied the change to their business operational. Afifah et al. (2018) mentioned that entrepreneurs is required to continuously search, learn, and implement it in their business strategy.

\section{Indirect Effect of Social Media Usage Variables}

The magnitude of a variable's effect on other variables in the model can be seen through direct or indirect influences. Table 2 indicates the significance of these variables. On the social media usage variable, social media for marketing had the greatest indirect effect on business performance through entrepreneurial marketing, with a value of 0.562 , compared to social media for information accessibility, which had a value of 0.331 . The indirect effect of social media for customer relation and service on business performance has a insignificant effect. This indicates that using social media for marketing and consistenly posting a variety of content, especially content that is interactive and persuasive with the audience, will improve the creativity of entrepreneurs in creating various ideas for innovation development. Innovation is not only about creating new products or services but also about creating new processes in running a business such as posting content that invites consumers to interact by giving likes, comments and sharing the post with others. So that the higher traffic of consumer engagement in posted content can create information to consumers about the existence and presence of organic processed foods on social media. It also affects the business performance of organic processed food business in terms of attracting new customers, increasing sales, and improving profitability.

\section{Managerial Implication}

Based on the result of study, social media was found to have effect on entrepreneurial marketing and business success. Entrepreneurs is expected to build audience by increasing the consistency of posting educative and persuasive content which encourage many audience to participate in the content shown. Educative content about the benefit and advantage of organic processed food should be packed with interactive and persuasive features on social media like quiz, polling, question and ask (QnA), microblogging, and even giveaway. Therefore, this activity is hoped for attracting many customers to participate in sharing the educative content with other users considering the bonus, lucky draw, or discount they will obtain. Moreover, this also indirectly educates society at broader level about organic processed food. Entrepreneurs could also create database contained the contacts of both old and new customers including the data of customer profile, cell phone number, social media account, email, and address. Therefore, entrepreneurs are able to ask for suggestion and input by involving customers in the process of improving product innovation or service, rewarding customer by personally giving customer loyalty, and establishing long-term relationship with customers. Entrepreneurs could also identify the characteristics of customers that is suitable to the organic processed food product offered. Social media provides information to entrepreneurs to specifically identify the characteristics of customers in term of behavior and psychograph.

\section{CONCLUSIONS AND RECOMMENDATIONS}

\section{Conclusions}

The use of social media significantly affected entrepreneurial marketing performed by organic processed food MSMEs. Entrepreneurial marketing is an appropriate way for entrepreneurs to grow idea and knowledge as a basis for promoting creation and innovation. Most entrepreneurs are already familiar with social media and use it to post various contents, communicate, serve, and establish relationship with customers, also search for information about the trend of customer flow change to further raise awareness and provide information about the presence of local organic processed food product. The use of social media together with the implementation of excellent entrepreneurial marketing will have effect on achieving the business success of organic processed food. 


\section{Recommendations}

This research has various scopes that limit the things studied. The wider scope of research can be continued as a point of view for future research. For example, in future research, a more diverse research sample with a larger number of respondents can be used. This study is limited in selection of samples. The sample only covered one community of organic food MSMEs. Future research should include respondents from various communities and different size of organizations to enhance the findings on the impact of social media usage. In this study, social media usage was categorized into three sub-constructs: social media usage for marketing, social media usage for customer relations and services, and social media usage for information accessibility. It is recommended for further study to include references related to the use of social media for other purpose in business, such as social media as content analysis tool to respond to market needs and achieve business success. This study investigated social media tools in general, future research can investigated one or several social media in specific. It considered that each social media has unique and different features, which might provide compatibility in targetting specific consumer that suitable with organic processed food consumer characteristics. Social media marketing strategy must be adapted to the chosen social media to be able to attract the desired response level from the specific segmen market. Moreover, the government relevant to this issue is expected to be able to quickly respond in collaboration with business community to promote local organic processed foods. Entrepreneurs should create marketing communication in increasing the value of organic processed foods, improving the strategy of market intelligence, and collaborating with similar businesses by organizing various events and collaborations.

\section{REFERENCES}

Asosiasi Penyelenggara Jasa Internet Indonesia. 2018. Penetrasi dan profil perilaku pengguna internet Indonesia. https://www.apjii.or.id. [24 Okt 2019].

Afifah AN, Najib M, Sarma M, Leong YC. 2018. Digital marketing adoption and the influences towards business successes of MSMEs creative sector in Indonesia and Malaysia. Journal of Applied Management 16(3): 377-386.
Agnihotri R, Dingus R, Hu MY, Krush MT. 2016. Social media: influencing customer satisfaction in B2B sales. Industrial Marketing Management 53: $172-180$.

Amalia KN, Mehendrawathi. 2019. Social Media Features For Improving Organization Business Performance: A Systematic Literature Review. Di dalam: Wibowo FW, Prayitno E, Nugroho $M A$, editor. Proceedings of the International Conference on Information System and Technology; Yogyakarta, 5-6 Des 2019. hlm 113-122.

Araujo T, Neijens P, Vliegenthart R. 2015. What motivates consumers to re-tweet brand content? Journal of Advertising Research 55: 284-295.

Arfanly B, Sarma M, Syamsun M. 2016. The role of entrepreneurial marketing in marketing performance improvement on home industry in Kendal Regency, Center Java. Jurnal Manajemen Pembangunan Industri Kecil Menengah 11(2): 141-150.

Azhar M, Akhtar MJ. 2020. Social media: a catalyst for entrepreneursip and marketing. South Asian Journal of Marketing and Management Research 10(11): 2249-877.

Becherer RC, Helms MM, McDonald JP. 2012. The effect of entrepreneurial marketing on outcome goals in SMEs. New England Journal of Entrepreneurship 15(1): 7-18.

Berthon PR, Pitt LF, Planger K, Shapiro D. 2012. Marketing meets web 2.0, social media, and creative consumers: implications for international marketing strategy. Business Horizons 55(3): 261-271.

Bocconcelli R, Cioppi M, Pagano A. 2017. Social media as a resource in SMEs' sales process. Journal of Business and Industrial Marketing 32(5): 693-709.

Buss O, Begorgis G. 2015. The impact of social media as a customer relationship management tool [master's thesis]. Sweden: Karlstad Business School.

Cappuccio S, Kulkarni S, Sohail M, Haider M, Wang X. 2012. Social CRM for SMEs: current tools and strategy. Communications in Computer and Information Science 332: 422-435.

Carson D, Gilmore A. 2000. Marketing at the interface: not 'what' but 'how'. The Journal of Marketing Theory and Practice 8(2): 1-7.

Coen B. 2016. Using social media for customer relationship management. Social Media 
Today.http://www.socialmediatoday.com/ social-business/using-social-media-customerrelationship-management. [17 Sep 2021].

Constantinides E, Romero CL, Boria MAG. 2008. Social media: a new frontier for retailers?. In European retail research (pp. 1-28) Wiesbaden: Gabler Verlag.

DeLone WH, McLean ER. 2003. The DeLone and McLean model of information systems success: a ten year update. Journal of Management Information Systems 19(4): 9-30.

Dey L, Haque SM, Khurdiya A, Shroff G. 2011. Acquiring competitive intelligence from social media. In proceedings of the 2011 joint workshop on multilingual OCR and analytics for noisy unstructured text data (pp. 1-9). https:// doi.org/10.1145/2034617.2034621.

Dodokh A, Al-Ma'aitah MA. 2019. Impact of social media usage on organizational performance in the Jordanian dead sea cosmetic sector. European Journal of Business and Management 11(2): 7591.

Dwivedi YK, Ismagilova E, Rana NP, Raman R. 2021. Social media adoption, usage and impact in business-to-business (B2B) context: a state-ofthe-art literature review. Information Systems Frontiers. https://doi.org/10.1007/s10796-02110106-y

Eid R, Abdelmoety Z, Agag G. 2019. Antecedents and consequences of social media marketing use: an empirical study of the UK exporting B2B SMEs. Journal of Business \& Industrial Marketing 35: 284-305.

ElliotR, BoshoffC.2005. The influence of organisational factors in small tourism business on the success of internet marketing. Management Dynamics 14(3): 44-58.

Evans D, McKee J. 2010. Social Media Marketing: the Next Generation of Business Engagement. Indiana: Wiley Publishing, Inc.

Ghozali I. 2008. Structural Equation Modelling Metode Alternatif dengan Partial Least Square. Edisi 2. Semarang: Badan Penerbit Universitas Diponegoro.

Ghozali I, Latan H. 2015. Partial Least Squares: Konsep, Teknik, dan Aplikasi Menggunakan Program SmartPLS 3.0. Semarang: Badan Penerbit Universitas Diponegoro.

Giannakouris K, Smihily M. 2013. Social media statistics on the use by enterprises. Eurostat. https://ec.europa.eu/eurostat/statistics-
explained/index.php/Social media - statistics on the use by enterprises.

Grossberg K. 2016. The new marketing solutions that will drive srategy implementation. Strategy \& Leadership 44: 20-26.

Guha S, Harrigan P, Soutar G. 2017. Linking social media to customer relationship management (CRM): a qualitative study on SMEs. Journal of Small Business and Entrepreneurship 30(4): $1-22$.

Hadiyati E. 2009. Kajian pendekatan pemasaran kewirausahaan dan kinerja penjualan usaha kecil. Jurnal Manajemen Kewirausahaan 11(2): 183-192.

Harris L, Rae A, Grewal S. 2008. Out on the pull: How small firms are making themselves sexy with new online promotion techniques. International Journal of Technology Marketing 3(2): 153168.

Hubeis M, Purwanto B, Dewi FR, Widyastuti H, Febtyanisa M. 2016. Daya Saing dan Prospek UMKM Pengolahan Pangan Lokal. Bogor: IPB Press.

Iblasi WN, Bader DMK, Al-Qreini. 2016. The impact of social media as a marketing tool on purchasing decisions. International Journal of Managerial Studies and Research 4(1): 14-28.

Ismail AR. 2017. The influence of perceived social media marketing activities on brand loyalty: the meditation effect on brand and value consciousness. Asia Pacific Journal of Marketing and Logistics 29(1): 129-144.

Jagongo A, Kinyua C. 2013. The social media and entrepreneurship growth (a new business communication paradigm among SMEs in Nairobi. International Journal of Humanities and Social Science 3(10): 213-227.

Jones B. 2010. Entrepreneurial marketing and the web 2.0 interface. Journal of Research in Marketing and Entrepreneurship 12(2): 143-152.

Jones R, Rowley J. 2011. Entrepreneurial marketing in small business: a conceptual exploration. International Small Businees Journal 29(1): $25-36$.

Katadata Insight Center. 2020. Digitalisasi UMKM di tengah pandemi Covid-19. https://katadata.co.id/ umkm. [28 Okt 2020].

Kazienko P, Szozda N, Filipowski T, Blysz W. 2013. New business client acquisition using social networking sites. Electronic Markets 23(2): 93103. 
Kementerian Koperasi dan UKM. 2018. Perkembangan data usaha mikro, kecil, menengah (UMKM) dan usaha besar (UB) tahun 2016-2017. https:// www.depkop.go.id/data-umkm.

Kimani E. 2015. Role of social media marketing on organisational performance in Kenya. Journal of Business and Management 17(1): 101-105.

Koç M, Dündar A. 2018. Research on social anxiety level and communication skills of secondary school students. Asian Journal of Education and Training 4(4): 257-265.

Kraus S, Harms R, Fink M. 2010. Entrepreneurial marketing: moving beyond marketing in new ventures.International Journal Entrepreneurship and Innovation Management 11(1): 19-34.

Marolt M, Zimmermann HD, Žnidaršič, Pucihar A. 2020. Exploring social customer relationship management adoption in micro, small, and medium sized enterprises. Journal of Theoretical and Applied Electronic Commerce Research 15(2): 38-58.

McKelvie A, Wiklund J. 2004. How knowledge affects opportunity discovery and exploitation among new ventures in dynamic markets. Research in Entrepreneurship and Management 4: 219-240.

Moen Øб, Madsen TK, Aspelund A. 2008. The importance of the internet in international business-to-business markets. International Marketing Review 25(5): 487-503.

Muzayanah FT, Suroso AI, Najib M. 2015. Faktor-faktor yang memengaruhi resistensi pembelian pangan organic dan proses pendidikan konsumen. Jurnal Manajemen dan Agribisnis 12(3): 163-173.

Ndiege JRA. 2018. Social media technology for strategic positioning of small and medium-sized enterprises: empirical evidence from Kenya. Electronic Journal of Information Systems in Developing Countries 85(1): 1-12.

Ojeleye YC, Opusunju MI, Ahmed AI. 2018. Impact of social media on entrepreneurship development among users in Zamfara state. Journal of Economics and Finance 2(2): 303-322.

Okoroma FN. 2018. Use of social media for modern reference service delivery in academic libraries in Nigeria. International Journal of Asian Social Science 8(8): 518-527.

Olanrewaju AST, Whiteside N, Hossain MA, Mercieca P. 2018. The influence of social media on entrepreneur motivation and marketing strategies in a developing country. Springer Nature Switzerland AG. 355-364. https://doi. org/10.1007/978-3-030-02131-3.

Papastathopoulou P, Avlonitis GJ. 2009. Classifying enterprises on the basis of WWW use: a behavioral approach. Internet Research 19(3): 332-347.

Park JY, Sung CS, Im I. 2017. Does social media use influence entrepreneurial opportunity? a review of its moderating role.Sustainability 9(9): 1593.

Parveen F, Jaafar NI, Ainin S. 2016. Social media's impact on organizational performance and entrepreneurial orientation in organizations. Management Decisions 54(9): 1-43.

Purnama C, Suyanto. 2010. Motivasi dan kemampuan usaha dalam meningkatkan keberhasilan usaha industri kecil (studi pada industri kecil sepatu di Jawa Timur). Jurnal Manajemen dan Kewirausahaan 12(2): 177-184.

Rana NP, Barnard BJ, Baabdullah AMA, Rees D, Roderick S. 2019. Exploring barriers of $\mathrm{m}$-commerce adoption in SMEs in the UK: Developing a frameworkusing ISM. International Journal of Information Management 44: 141153.

Reijonen H, Pardanyi S, Hirvonen S, Laukkanen T. 2012. Entrepreneurial marketing orientation (EMO): an empirical test. Di dalam: Campbell $\mathrm{C}$, Ma J, editor. Looking Forward, Looking Back: Drawing on the Past to Shape the Future of Marketing. Development in Marketing Science. Proceedings of the European Marketing Academy Conference 2012; 2012 May 22-25; Portugal, Lisbon.

Richard PJ, Devinney TM, Yip GS, Johnson G. 2009. Measuring organizational performance: towards methodological best practice. Journal of Management 35(3): 718-804.

Rusminah S, Sarma M, Munandar JM. 2018. The influencing factors of competitiveness in small and medium enterprises in Indonesia. International Journal of Research \& Review 5(11): 28-36.

Samat MF, Yusoff MNH, Ismail M. 2018. The mediating effect of social media marketing adoption between competitive intelligence and SME performance. International Journal of Asian Social Science 8(7): 379-387.

Sarma M. 2013. Entrepreneurial Marketing untuk Keberhasilan Pemasaran bagi Usaha Mikro, Kecil, dan Menengah (UMKM) Indonesia. Bogor: IPB Press.

Saavedra FU, Andreu JL, Criado JR. 2012. Social 
Media Marketing Intensity: Its Impact On The Relation Among Market Orientation, Entrepreneurial Orientation and Performance. Di dalam: Campbell C, Ma J, editor. Looking Forward, Looking Back: Drawing on the Past to Shape the Future of Marketing. Development in Marketing Science. Proceedings of the European Marketing Academy Conference; Portugal, 2225 May 2019.

Scheiner CW. 2014. The importance of social media as source of information in the technology identification in dependence of external and internal factors. Springer International Publishing Switzerland 8531: 103-112.

Shiau WL, Dwidevi YK, Yang HS. 2017. Co-citation and cluster analyses of ecxtanliterature on social networks. International Journal of Information Management 37(5): 390-399.

Singh RK, Garg SK, Deshmukh SG. 2008. Strategy development by SMEs for competitiveness: a review. Benchmarking: An International Journal 15(5): 525-547.

Singh TP, Sinha R. 2017. The impact of social media on business growth and performance in India. InternationalJournal of Research in Management \& Business Studies 4(1): 2348-6503.

Sivarajah U, Irani Z, Gupta S, Mahroof K. 2019. Role of big data and social media analytics for business to business sustainability: a participatory web context. Industrial Marketing Management 86: 163-179.

Srinivasan R, Moorman C. 2005. Strategic firm commitments and rewards for customer relationship management in online retailing. Journal of Marketing 69(4): 193-200.
Stokes D. 2000. Entrepreneurial marketing: a conceptualisation from qualitative research. Qualitative Market Research: An International Journal 3(1): 47-54.

Stone RW, Good DJ, Baker-Eveleth L. 2007. The impact of information technology on individual and firm marketing performance. Behaviour \& Information Technology 26(6): 465-482.

Sufian A, Min CS, Murad MA, Aziz NAA. 2020. The impact of social media marketing on sales performance of small online business. European Journal of Molecular and Clinical Medicine 7(3): 922-940.

Sunar MSM, Shaari AJ. 2017. The effectiveness of the chemistry PBL method via Facebook on the soft skills of college students. Asian Journal of Education and Training 3(2): 97-104.

Teo TS, Choo WY. 2001. Assessing the impact of using the internet for competitive intelligence. Information \& Management 39(1): 67-83.

Walsh MF, Lipinski J. 2009. The role of the marketing function in small and medium sized enterprises. Journal of Small Business and Entreprise Development 16(4): 569-585.

WibowoA, Chen SC, WianginU,MaY,Ruangkanjanases A. 2020. Customer behavior as an outcome experience. Sustainability 13(1): 1-18.

Wu Y, Pei Z. 2018. An investigation of critical thinking manifested in the questions of EFL textbooks for tertiary-level english majors of China. American Journal of Education and Learning 3(2): 72-84.

Yoon SB, Cho E. 2016. Convergence adoption model (CAM) in the context of a smart car service. Computers in Human Behavior 60: 500-507. 